\title{
Polarized pluralistic model: Characteristics of Nepalese press
}

Bhuwan K.C.

\begin{abstract}
This paper presents a comparative study of Media System in the context of Nepal on the basis of Hallin and Mancini's study. The paper shows that the characteristic of Nepalese press match with the polarized pluralistic model, which is prevailed in Southern European states. This study also helps to understand the effect of political parallelism in professionalism of Nepalese press.
\end{abstract}

Keywords: Political system, Media, Polarized pluralist, Political parallelism, Professionalism.

\section{Introduction}

Choosing a political system to large extent is like choosing a communication system (Sommerland, 1975). Nepal's political system has witnessed changes and continuity from autocratic ruling system to the democratically elected form of governance. It has witnessed the direct rule of the King Until April, 2006 and turned into a republic state with democratically elected government from 2008. Nepalese media have faced the brunt of censorships during the autocratic form of governing system, whereas it has also been 
able to enshrine 'full press freedom' after adopting the Constitution of Nepal in 2015. Thus, the changing forms of political system in Nepal have resulted different approach of communication. So, understanding political system in the context of Nepal is also a way of understanding the media system. However, it is difficult to identify the model of press system that Nepal follows because it requires an intensive research. Research in the international front has identified similar patterns of model that has been adopted in Nepal. The model proposed by Daniel C. Hallin and Paolo Mancini (2004) in their work Comparing Media System is indeed a resourceful document in the context of Nepal to understand the media model. Based on the models proposed by Hallin and Mancini (2004) this paper seeks to understand that whether Nepalese media system can be incorporated under the model as defined or it requires some changes with respect to different society and political system of Nepal.

The study finds that Nepalese media system is highly similar to the Polarized Pluralistic model identified by Hallin and Mancini (2004). Nepalese media mark the similar characteristics of weaker historical development of commercial media and a strong role of the state. And other similar aspects are low circulation, high political parallelism, weaker professionalism, government subsidies and strong government intervention at times.

\section{Media and Politics}

Scholars have attempted to understand the relationship between media and politics. They have tried to understand the 
function of the press based on the political ideological grounds in the international front. One of the study, which remained highly influential was Four Theories of Press by Frederick S. Siebert, Theodore Peterson, and Wilbur Schramm in 1956.

It has been argued that the press takes on the form and coloration of the social and political structures within which they operate. Siebert, Peterson, and Schramm assumes that media is a dependent variable in relation to social system which it reflects. Media is also viewed as reflective or independent influential, especially in the political system. Therefore, Hallin and Mancini (2004) argued that Four Theories of the Press should be given a decent burial and move on to the development of more sophisticated models based on real comparative analysis.

Hallin and Mancini (2004) used the comparative analysis in their study to understand the relationship between media and political system of the United States, Canada, and most of the Northern and Western Europe. ${ }^{1}$ They have identified three models in media system in their study; Liberal, Democratic Corporatist and Polarized Pluralist model.

Liberal Model prevails over Britain, Ireland, and North America and is characterized by the dominance of market mechanisms and commercial media, information oriented

1 Countries selected for the study are United Kingdom, United States of America, Canada, Ireland, Austria, Belgium, Denmark, Finland, Germany, Netherland, Norway, Sweden, Switzerland, France, Greece, Italy, Portugal and Spain. 
journalists, internal pluralism, professional model of broadcasting, self-regulation and market driven journalism in which, state can't interfere the media.

Democratic Corporatist Model is found in the countries of northern continental Europe i.e. Austria, Belgium, Denmark, Finland, Germany, Norway, Sweden and Switzerland. In these countries, media and commercial media were historically coexisted and tied to organized social and political groups in which the state has relatively active but legally limited role. Other features of this model are higher circulation of newspapers, external pluralism, development of commercial press, strong party press, strong state intervention with protection of press freedom, government subsidies and the existence of strong public broadcasting service.

Finally, Polarized Pluralist Model prevails in Mediterranean countries of southern Europe i.e. France, Italy, Greece, Portugal and Spain. The major characteristic of this model is the integration of media into party politics, with weaker historical development of commercial media and a strong role of the state. Other characteristics are low circulation, elite political orientation, high political parallelism, external democracy, commentary oriented journalism, government model of broadcasting, weaker professionalism, government subsidies and strong government intervention.

However, studying the characteristics of developing countries based on the models identified by Hallin and Mancini (2004) is not an easy task. Voltmer (2008) points out that the relationship between the media and their political, economic and cultural environment suggests the emerging democracies develop unique types of media system that significantly 
differs from those of established democracies. On the other hand, partisan journalism also influenced the news content. Partisanship intrudes on news decisions to a measurable degree among both print and broadcast journalists at both the national and local levels (Patterson and Wolfgang, 1996).

Colin Spark talking about different model for Russia and China states that it is pretty obvious that most of the system in Central Europe fit well into the polarized political model that they identify as present in Mediterranean Europe, and it is fairly simple to generate a new, fourth, model-authoritarian corporatist-that can be used for Russia and, perhaps, even China (Spark, 2010).

Richani (2012) argues that the media market, political parallelism, state role and professionalism as identified in the West world as key component of media system may fail to reveal any pattern when applied to rest of the world.

Bringing into understanding of a model in the context of Nepal that suits as per the model discussed by Hallin and Mancini (2004), it is necessary to understand the historical press and political system and the society through which media has evolved.

\section{Nepalese Politics and Media Environment}

Mass media in Nepal made its debut through state initiation. Nepali mass media have always been influenced by the political changes in the country (Adhikary, 2007). The development of mass media environment in Nepal can be 
divided into different phases; a) Before1951, b) from 1951 to1960, c) from 1960 to 1979 d) from 1979 to1990 and e) after 1990. It was only in 1851 with the arrival of printing press and publication of weekly newspaper Gorkhpatra in 1901thatmarked the beginning of media in Nepal. This is the period of authoritarian Rana regime (1846-1950), that suppressed diverse opinion and opposition politics. Press which were allowed to run its affairs apart from state run, had to obtain license and criticism of the ruler was forbidden. Until the fall of Rana regime printing presses and publication houses were beyond the reach of people. Presses were in the grip of Ranas, their relatives, gurus and few rich individuals having pleasant relationship with the Ranas (Adhikary, 2007).

In a true sense, with the overthrown of the Ranas the press in Nepal started only in 1050, although crusading literacy journalism had started long before among the exiled Nepalese in India and a small-Nepali language press was also set up at the turn of the century among the Nepali diaspora in North and North-Eastern India (Adhikary, 2003).

Dahal (2015) argues that the practical history of newspapers began after the fall of Ranas in 1951, when several pioneering journalists took to publishing newspapers in a transitional democracy. After the revolution of 1951, opinion about for and against in Nepali Journalism started to flow freely (Dahal, 2015). However, thirty years period after the royal takeover in 1960 represented a repressive press system. The political parties were banned and active leadership of King prevailed. From 1979-1989 although the political parties were continued to be banned but newspapers became bolder and started to give an alternative political view. During this time, press 
enjoyed limited rights and lobbied, to some extent, for a multiparty democracy that could guarantee press freedom (Kharel, 2006). Journalism was taken as a mission during the party less Parchyat era (Khanal, 2001). The Nepali press as it was then had very little room for criticism (Shrestha, 2003). Private media were also used to get advertisement and certain discount in newsprint from the government. Few journalists, who had close relationship with the government got printing press ${ }^{2}$ Mission journalism, which supported the democratic ideology got hindrance from government time and again. The private sector media had to struggle for survival at times even by compromising their interests with those in power.

Journalists were divided into two fractions; to support extremely and to do advocacy of people's right and freedom. Previous groups used government facilities whereas next groups faced physical attack, defame and punishment (Dahal, 2015). Self-censorship could have existed among journalists working in the privately-run media at the time. But, because most of these papers often had an ideological bent, it would be logical to assume that the content was not only influenced by government rules but also by the party affiliations of the editors and reporters (Bhattarai \& Mainali, 2014).

The seed of political parallelism was thus sowed during this period, where journalists near to the political elite and supportive to the state were allowed to function. Media professionalism known as such today was irrelevant and press freedom was out of reach. Despite the rise in quantity in number of newspapers and media outlets, Nepalese press still

2 Tirtha Koirala, personal communication, 2 May, 2013. 
suffers the accusation of being partisan and lack of professionalism. Nepalese media scholars have observed that partisan press have affected Nepalese journalists and their professionalism where Nepal continues to have partisan media because media willingly function in such manner (Aditya 1996, p. 66-67; Kharel 2010, p. 67-68). After 1990, print industry becomes one of the competitor industry and increases professionalism in contents too (Acharya, 2014).

Until 1990s mass media in Nepal was considered to be a national project. The change in political system in 1990s from party less Panchayat System to multiparty democratic system heralded the rise of media outlets ${ }^{3}$ in Nepal, with private investment. The political change came as a major landmark in opening up a new era of liberalism and freedom in the country (Shrestha, 2003). After the restoration of democracy in 1990, the environment of professional journalism with large investment in media sector developed. The Constitution of the Kingdom of Nepal (1990) formally guaranteed the freedom of press and publication as fundamental rights in Article 12 and 13. It change in legal system: second is the increasing involvement of private party and NGOs in both media production and education; third is cumulative growth in the media advisement market; fourth is the growth in the number of Nepal is who consume media products; and fifth is the imperative of the Nepali Language (Onta, 2006). And daily

3 Media outlets in Nepal: according to Press Council Nepal report 2017, 863 published newspapers among with 183 are daily and 636 are weeklies with total registration of 3865 ; according to ministry of communication and information technology (accessed January 8, 2019) radio granted license is 740 and television license granted number is 116 . 
papers like Kantipur and Kathmandu Post begin to publish from 1993. The restoration of multiparty democracy in 1990s has boosted media industry in Nepal. It was since this period media houses were granted licenses which resulted to mushrooming growth for newspapers, Frequency Modulation (FM) radio and private television channels in Nepal.

However, Nepal was caught in the civil war since 1996 when armed rebel Communist party of Nepal (Maoist) announced war against the state. The effect of Maoist rebel started to be felt since 2001 after its attack on army barrack in Dang district. Later the state declared state of emergency, where fundamental rights of the citizens were curtailed. Journalists those who supports the Maoist were either arrested or killed. During the emergency period, more than 106 journalists were arrested and nine journalists were killed (Kafle, 2003). Nepalese press faced problems and challenges both by the state and the Maoist rebel during this period until 2006. The frequent skirmishes between the leaders of political parties and the press tell of deep distrust between the two. Time and again reporters have been taken into custody, arrested or detained on flimsy grounds and journalists have been harassed, manhandled, maimed, kidnapped and even murdered. The accusations against the state media regarding news blackouts, falsifying information and muffling the public voice, instead of dying out gradually has ironically, reached new heights (Shrestha, 2003).

Despite all the constitutional guarantees, violations continued. The press was gagged when King Gyanendra took direct control of power in 2005, citing that the government could not maintain law and order situation and Communist 
Party of Nepal Maoist which had waged People's War since 1996. The Royal government passed Media Ordinance in October, 2005 to silence media in Nepal. The royal regime treated journalists and press in an uncivilized and imprudent way. Independent Nepalese media became victim of such a treatment of the royal regime directly (Gaule, 2006).

The People's Movement-II of 2006 that restored the Parliament, Constituent Assembly election turned Nepal into a republican state. Now the country is governed by a new Constitution, which guarantees the press freedom and freedom of expression as people's fundamental rights4.

4 Right to communication: (1) No publication and broadcasting or dissemination or printing of any news item, editorial, feature article or other reading, audio and audio-visual material through any means whatsoever including electronic publication, broadcasting and printing shall be censored.

Provided that nothing shall be deemed to prevent the making of Acts to impose reasonable restrictions on any act which may undermine the sovereignty, territorial integrity, nationality of Nepal or the harmonious relations between the Federal Units or the harmonious relations between various castes, tribes, religions or communities, or on any act of sedition, defamation or contempt of court or incitement to an offence, or on any act which may be contrary to public decency or morality, on any act of hatred to labour and on any act 
The launch of private news media has changed the mediascape in Nepal. The last two decades show corporate and business interest has risen than ever before, "almost all major media in Nepal are the result of diagonal (conglomerate) ownership, with proprietors already having other businesses before venturing into the media business" (Kharel, 2012).

of incitement to caste-based untouchability as well as gender discrimination.

(2) No radio, television, on-line or other form of digital or electronic equipment, press or other means of communication publishing, broadcasting or printing any news item, feature, editorial, article, information or other material shall be closed or seized nor shall registration thereof be cancelled nor shall such material be seized by the reason of publication, broadcasting or printing of such material through any audio, audio-visual or electronic equipment. Provided that nothing contained in this clause shall be deemed to prevent the making of an Act to regulate radio, television, online or any other form of digital or electronic equipment, press or other means of communication.

(3) No means of communication including the press, electronic broadcasting and telephone shall be interrupted except in accordance with law. 
On the other hand, there remains political parallelism and lack of professionalism in the Nepalese press.

In its strict sense, "profession" refers to a certain small class of occupations with special characteristics that set them apart from mere trades or business. These professional occupations are afforded special privileges and high status (Hodges, 1986). According to Bacon (2000), professions are historically understood as a "privileged class of occupations," characterized by discourses that suggest highly trained expertise, selection by merit, and peer surveillance of ethical or rigorous application of that expertise (Bacon, 2000).

The articulation of this social and cultural authority through an institutionalised formation of journalism as a "profession" has underlined contemporary attempts to privilege the role of the journalist and its responsibilities. Understanding of journalistic professionalism has revolved around the acknowledgement of the centrality of news production to contemporary political, social and cultural governance (Bossio, n.d.).

Party journalism will create various side effects on a capable journalist among which five major effects are given below; first, there will be no self-conscious in party journalist. They have to analyze the in portal subject matter on the basic of party thought. The party will teach to criticize the truth which is not in favor of the party. Slave phycology will be developed slowly in these journalists. They will never believe in their capacity rather dream to rise above on someone's favor of (Acharya, 2017). 
Politicization continues to overwhelm the media sector. The media, no matter state-owned or privately run, have not been able to make departure from political obligations (Khanal, 2001). The media looked and analyzed these events and issues in their own way but sadly mostly from partisan angles (Shrestha, 2003).

Media is getting increasingly aligned with one or the other side of the political poles, will have far less positive impact that a professional and objective media could have contributed in the process (Ghimire, n.d.). Parties press also flourishes. There is some truth in the belief that if one is to get reliable information on a particular issue, then one must read papers that are mouthpieces of the ruling party, the opposition and those that are presumably neutral and then form an opinion (Shrestha, 2003). Shrestha stated that even a casual look into its present state of affairs shows that it is still afflicted by two basic maladies namely, the long-felt absence of a truly independent and competitive media in the private sector; and the other, the dominant role of the state-owned media.

Political affiliation has affected professionalism. The lack of professionalism, resulting from partisanship and low capacity, is another factor leading to self-censorship (Bhattarai and Mainali, 2014).

At present, Nepal has a new constitution, adopted after the elections of second phase of Constituent Assembly Elections in 2013. The Constitution of Nepal 2015, in its preamble has guaranteed 'full press freedom.' Nepal has also adopted the federalism as envisaged by the Constitution and has held three tiers of elections at the Federal, Provincial and Local level. 
Nepalese media saw division during the elections of three tiers of government. The monitoring reports of elections on the three tiers of government by Center for Media Research Nepal (2017) shows that online news media was highly partisan flow of news whereas mainstream print media were quite neutral. It points out to the fact that political parallelism was widely witnessed in the online news media outlets in Nepal.

The government at the three tiers is in the process of drafting new laws regarding media. In the process of forwarding the draft media laws at different levels, there are some points in drafts laws which are against the articles about press freedom mentioned in the constitution (FNJ Annual Report, 2018). According to FNJ, there were 58 cases of press freedom violation noted in 2018 which is less than previous year. Although, this year became challenging because of legal side. $^{5}$

\section{Characteristics of Nepalese Press: Polarized Pluralistic Model}

Observing the historical phase of Nepalese media, the major characteristics of Nepalese press can be based on polarized pluralistic model of Hallin and Mancini. The historical development of media in Nepal clearly shows the emergence of Nepal's democratic transition from authoritarian system. Democracy was lately introduced despite some events which

5 Condition of Nepalese press in 2018. Retrieved January 12, 2019 from http://fnjnepal.org/en// 
have played a crucial role in the past by the King in affecting the democratic system. During the 39 years of democracy in the history of Nepal, none of the government could ever work for full five years' time due to the lack of political culture in political parties. After the Declaration of Constitution of Nepal from Constitution Assembly in 2015, holding local level, province level and federal level election and formation of present government in 2018 shows that political parties have succeeded to end political transition in the country.

Strong state interventions have been observed in the past, with restriction and censorship by the state authority in times. If we analyze the newspaper industry, political parallelism, professionalism, role of the state in media system we can observe the characteristics of Polarized pluralistic model in Nepal that are described below:

\begin{tabular}{|l|l|}
\hline Characteristics & Nepal \\
\hline Newspaper Industry & $\begin{array}{l}\text { Low newspaper circulation; elite } \\
\text { politically oriented. No exact data of } \\
\text { circulation. According to Press } \\
\text { Council Nepal, 3665 newspapers } \\
\text { were registered but only 607 } \\
\text { newspapers publish regularly. }\end{array}$ \\
\hline
\end{tabular}

6 Press Council Nepal Anual Report. Retrieved January 1, 2019 from http://www.presscouncilnepal.org/np/wp-content/uploads/2017/10/finalreport-48-finel.pdf 


\begin{tabular}{|c|c|}
\hline Political Parallelism & $\begin{array}{l}\text { High Political parallelism; } 13,050 \\
\text { journalists are affiliated with the } \\
\text { Federation of Nepalese Journalist, } \\
\text { however, more than } 24000 \text { journalists } \\
\text { are affiliated to partisan media } \\
\text { organization group. }\end{array}$ \\
\hline Professionalization & $\begin{array}{l}\text { Weaker professionalization; Big } \\
\text { media houses are comparatively } \\
\text { better than small and partisan media. } \\
\text { Even though, they have problems. } \\
\text { Journalists have difficulties in getting } \\
\text { minimum wage in media houses. }\end{array}$ \\
\hline $\begin{array}{l}\text { Role of the state in } \\
\text { Media system }\end{array}$ & $\begin{array}{l}\text { Strong state intervention has been } \\
\text { observed in the past as there were } \\
\text { period of censorship. State provides } \\
\text { subsidies in newsprint and also } \\
\text { provides advertisements to the media } \\
\text { houses. State is the largest advertiser } \\
\text { occupying one fourth of the total } \\
\text { advertising industry. }\end{array}$ \\
\hline $\begin{array}{l}\text { Political History } \\
\text { Patterns of Conflict } \\
\text { and Consensus } \\
\text { Individual Vs } \\
\text { Organized Pluralism }\end{array}$ & $\begin{array}{l}\text { Late democratization Polarized } \\
\text { pluralism, Mixed (consensus among } \\
\text { major political parties and rest are } \\
\text { polarized) politics. }\end{array}$ \\
\hline
\end{tabular}


State has been providing subsides to the media houses, more liberal to the press than the broadcast. Government provides subsides to the press, deduction of tax for press in the newsprints, also by providing advertisement to the media. Nepal government is the largest advertiser in Nepal that occupies one- fourth of the total advertising industry, with amount of Rs.1 billion in advertisement (Prajapati, 2013).

Another characteristic is low newspapers circulation. Only some professional papers have high circulation. Kantipur Daily, largest selling newspaper of Nepal, claimed circulation $448,000^{7}$ which covers 1.69 percent of the total population. The overall print circulation is low because of the difficult geographical terrain, the high recurring costs for both publishers and readers, and the adult literacy rate at only around 60 percent of the population. Newspapers are mainly sold in the Kathmandu Valley and cities, thus having a greater impact on political and policy issues (Acharya, 2016).

Publishers often exaggerate their claimed their circulation. The top circulating dailies are generally oriented towards the center of the political spectrum, but no newspapers in Nepal publicly declare their political leaning.

In term of ownership, there are two types of media in Nepal; government and private. There are three categories in private media; commercial/professional, community and cooperative. Government runs Television, Radio,

7 Kantipur. Retrieved 31 December, 2018 from http://kmg.com.np/kantipur-publication/\#Kantipur. 
Newspapers and News Agency. Ideally, these are autonomous but they are not autonomous in practice.

Some big media houses in Nepal like Kantipur Group, Nepal Republica House which dominates the mediascape are claimed to be professional. However, in certain instances their stance in certain news content are politically biased, and in most of the instances economic factor influences the news content of the media.

According to the study of Prajapati, those who received advertising from Dabur Nepal, ignored the news about the allegation that the Dabur Nepal products were substandard, whereas those who did not get advertisements highlighted and extensively covered incidents that proved the Dabur Nepal products to have been of low quality. In both cases the news media were trying to protect their corporate interest (Prajapati, 2012).

Former News Chief of Kantipur Television argues that the main stream media are in illusion. They have no clear destination. There is one kind of anarchism. ${ }^{8}$ And many small media, community media and cooperative media are also not free from partisan interest. These have affected the professionalism of the press. Another problem that has marred the media industry is that journalists are unpaid for months, which have increased the tendency of highly paid news which are observed in the broadcast media houses.

Another factor that has affected professionalization is political parallelism. It is high in the context of Nepal, because

8 Tirtha Koirala, personal communication, 2 May, 2013. 
of high level of partisan interest in the news media. Research showed that journalists associated with weekly newspapers support a political ideology and political parties (Pathak, 2007), but its impact in the newsroom of daily newspapers are difficult to be addressed despite some claims made by the editors, who say there are political parties' cadres working in the daily newspapers. ${ }^{9}$ Another study showed 17 percent journalists, who have political beat in daily newspapers, had parties' affiliation (K.C., 2014).

Many journalists are affiliate with the political parties' wing. The data of Federation of Nepalese Journalists (FNJ) shows that 13,050 journalists are member of the organization. ${ }^{10}$ According to the data provided by the political parties affiliated journalist organization reveals a shocking picture. Press Chautrari Nepal and Press Center Nepal affiliated to Communist Party of Nepal has 17,000 member journalists, Press Union affiliated to Nepali Congress has 7300 journalists as member. ${ }^{11}$ Almost all political parties have journalist's organization. Politically Journalists were directly divided in FNJ election and political parties and government had keen interest and interferes in election. Alliance of Press Union (Journalists' organization who support Nepali Congress) and Press Center Nepal (Journalists' organization who support Nepal Communist Party-Maoist (Kendra) and others defeated

9 Yuvaraj Ghimire claimed that journalists in the daily newspaper in Nepal were affiliated to political parties. Paper Presented in a program organized by Outline Media January 27, 2014.

10 Members. Retrieved 31 December, 2018 from http://fnjnepal.org/en/page/members 11 Ganesh Basnet, President of Press Chautari Nepal, Ajaya Babu Shiwakot, General secretary of of Press Union, personal communication in January 1, 2019. 
the Journalists, who supported Nepal Communist Party (UML).

There is weaker development of rational-legal authority. Press council Nepal has major responsibility to monitor journalistic code of conduct. It does not have sufficient infrastructures and manpower to monitor Television and Radio. There is not strong self-regulation mechanism. Many Media houses don't prepare own code of conduct for the journalists and don't keep ombudsman. Therefore, there are problems in media.

Government run Rastriya Samacha Samitee (New Agency, Radio (Radio Nepal), Television (Nepal Television), News papapers (Gorkhapatra, The Rising Nepal). These media play of mouthpiece of state. Government provides financial support to different organizations of Journalists. In 2017 Government allocated RS.3.8 million for Journalists and publishers' organizations. ${ }^{12}$

The Nepali government spends a considerable amount of public funds each year in the name of public welfare advertising. According to the Red Book of 2014-2015, it earmarked NRs 16, 16, 25,000 to distribute to the Nepali media in return for carrying welfare advertising across multiple mediums (Maharjan, 2014). The study showed that the various policy measures related to welfare advertising have used public welfare advertising as a front for financially supporting the various media institutions. The disregard for

12 The lists of organizations to whom Ministry of Communication distributed RS.3.8 million (Sanchar Mantralayale 38 lakh Ka Kaslai Badeo (Suchi Sahit). Retrieved January 1, 2019 from https://www.onlinekhabar.com/2017/06/602037. 
the true purpose of welfare advertising and the benefits it can offer to the general public has meant that large amounts of the public funds have been misused (Maharjan, 2014).

\section{Conclusion}

Media and political system have strong relationship with each other because one system has impact on another and vice versa. From the very beginning of the development of media and political system till date both have faced ups and down. The overall study shows that the characteristics of media is basically very much similar to the pluralist polarized system. But, time and again the characteristics of other models like tendency of corporate media system and liberal model has been noticed. Most of the Nepalese media and journalists have direct or indirect connection with political parties. Majority of journalists have affiliation with the journalists' organization which are proved and guided by political parties. The number of journalists taking membership of organization guided by political parties is far more than the membership of Federation of Nepalese Journalists. Ruling parties and opposition parties used to have direct interference in the candidate selection process and during the election period of Federation of Nepalese Journalists. State runs news agency, radio, TV and newspaper by itself and. The changes in government have impact in leadership and content of government run media. In crucial situation, media and journalists who claim to be professional show political biasness.

The constitution has guaranteed the press freedom but there is problem while practicing it. The act of violation of freedom is 
seen time and again. Media have faced censorship during the royal takeover period. This shows that media and government have tussle between them. While there was threat to democracy and democracy was collapsed by the king media have also conducted mission journalism to support democracy. In the recent time, various media related laws and policies is being formulated at central, province level and local level but there are some provisions which curtails freedom of expression and press.

In conclusion, Nepal highly falls under the pluralist polarized model, with weaker historical development of commercial media and a strong role of the state, which has low circulation, high political parallelism, weaker professionalism, government financial support and strong government intervention at times. Although Nepal is now a republic country and there is provision of press freedom in constitution the study shows that it is very difficult to maintain standard and professionalism in journalism

\section{References}

Acharya, Bhanubhakta. (2017). Election of FNJ \& Side effect of journalism (Patrakar Mahasangko Chunab ra party patrakariko side effect). Retrieved January 2, 2019 from https://www.onlinekhabar.com/2017/02/546876.

Acharya, Prakash. (2014). 'Professional Journalism' (Bayabsayik Patrakarita). Media Reader, Deepak Aryal, Bhuwan K.C.\& Tipak Pathak (ed) P.42-52. Lalitpur: Jagadamba Prakashan. 
Acharya, Ujjwal. (2018). Nepal-Media Landscape. Retrieved January 1, 2019 from

https://medialandscapes.org/country/pdf/nepal.

Adhikary, Nirmala Mani. (2007). Mass Communication and Journalism. Kathmandu: Prashanti Prakashan.

Aditya, A.(ed). (1996). Mass Media and Democratization A Country Study of Nepal ( $1^{\text {st }}$ ed). Kathmandu: IIDS.

Ahikary, Dharma. (2003). Nepali Journalism: Then and now. Nepali Press During State of Emergeny, Chiranjibi Kafle (ed) P.1-7. Kathmandu: Federation of Nepalese Journalists.

Bacon. W. (2006). Journalism as research. Australian Journalism Review, 28(92), 147- 157.

Bhattarai, Binod \& Mainali, Raghu. (2014). Killing Journalism Softly. Kathmandu: Alliance for Social Dialogue \& The Writing Workshop.

Bossio, Dianna. (n.d.). Defining 'Professionalism' within tertiary Journalism Studies. Retrieved January 1, 2019 from https://www.anzca.net/documents/2010-conf-papers/463defining-professionalism-within-tertiary-journalism-studies1/file.html

Dahal, Homnath. (2015). Mission journalism for democracy: My Experience (Prajatantaka lagi Mission Patrakarita). Media Adhayan, Devraj Humagain \& others (ed) P. 171-180. Kathmandu: Matrin Chautari.

Dahal, Rishikesh. (2014). Newspapers Journalism (Akhabari Patrakarita). Media Reader, Deepak Aryal, Bhuwan K.C.\& Tipak Pathak (ed) P. 31-41. Lalitpur: Jagadamba Prakashan.

Daniel C., Hallin \& Mancini, Paolo. (2004). Comparing Media Systems Three models of media and politic. Cambridge: Newyork. 
Gaule, Shiva. (2006). Journalism Under Royal Regime. Under Royal Regime, Kiran Chapagain (ed) P.1-5. Kathmandu: Federations of Nepalese Journalists.

Ghimire, Y. (n.d.). Nepali Media at Crossroad: Can they Mediate Constitution-Making and Peace Processes? Retrieved May 19, 2013 from

http://www.nepaldemocracy.org/media/nepali_media_at_cr ossroad.htm

Hodges, Louis W. (1986). The Journalist and Professanalism.

Retrieved January 2, 2019 from http://scihub.tw/10.1080/08900528609358264

Kafle, Chiranjibi (ed). (2003). Nepali Press During State of Emergency. Kathmandu: Federation of Nepalese Jouranlists.

K.C., Bhuwan. (2014). Political Inclination of Journalists \& its influence in news. Retrieved, January 2, 2019 from http://research.butmedia.org/wpcontent/uploads/2017/02/PoliticalInclination.pdf

K.C., Bhuwan \& Joshi, Hiranya (ed). (2018). Press Freedom \& Journalist Safety Annual Report (Press Swatranta ra Patrakarko Surakshya Barsik Partibedan. Kathmandu: Federation of Nepalese Journalists.

Khanal, Chiranjibi. (2001). Functioning of print media problems and prospects. Media issues in Nepal. Kharel, P (ed) P. 111126. Kathmandu: Nepal Association of Media Educators.

Kharel, P. (2001). Functioning of print media problems and prospects. Media issues in Nepal. P. Kharel, (ed) p. 1-20. Kathmandu: Nepal Association of Media Educators.

Kharel, P. (2006). A Study of Journalism. $1^{\text {st }}$ ed. Kathmandu: Nepal Association of Media Educators. 
Kharel, P. (2010). Political Communication: Media, Message and Meaning. $1^{\text {st }}$ ed. Kathmandu: Sangam Institute.

Kharel, P. (2012). Media for Participatory Democracy.

Kathmandu: Supravaha Prakashan (P.) Ltd.

Maharjan, Harsha Man. (2014). Rethinking Public Welfare Advertisement in Nepal: From Media Welfare to Public Welfare. Retrieved January 11, 2019 from http://asd.org.np/wp-content/uploads/2015/03/RethinkingPublic-Welfare-Advertisement.pdf

Media Monitoring. (2017). Kathmandu: Center for for Media Research, Nepal (Unpublished).

Onta, Pratyoush. (2006). Mass Media in Post-1990 Nepal. Kathmandu: Martin Chautari.

Patterson, Thomas E. \& Donsbagh, Wolfgang. (1996). News decisions: Journalists as partisan actors, Political Communication, 13:4, 455-468, DOI: $10.1080 / 10584609.1996 .9963131$

Pathak, Tilak. (2006). Impact of political affiliation in writing in weekly papers. Kathmandu: Tribhuwan University (unpublished, thesis).

Prajpati, Uiiwal. (2013). Safeguarding Public Interest in the era of Corporate Media: Case studies on Impact of Ownership on News Content. Retrieved January 11, 2019 from http://research.butmedia.org/wpcontent/uploads/2013/09/saf eguarding_public_interest_in_the_era_of_corporate_media UjjwalPrajapati.pdf

Prajapati, Ujjwal. (2013). Understanding Advertising and Public Relations: Effects in News Media. Selected Media Topic, P. Kharel (ed), P. 102-160. Kathmandu: Central Department of Journalism and Mass Communication. Tribhuvan University. 
Richani, Sarah El. (2012). Comparing Media System in the 'West' and beyond. Retrieved January 5, 2019 from https://www.dbthueringen.de/servlets/MCRFileNodeServlet/dbt_derivate_0 0026501/GMJ4_Richani_final.pdf

Shrestha, Anada P. (2003). Media, Development and Democracy. Seminar paper. Kathmandu: The Telegraph weekly(TW)/Friedrich-Ebert-Stiftung (FES).

Sommerland, E Llyod. (1975). National Communication System: Some policies Issues and Opinions. UNESCO.

Spars, Colin. (2010). China's media in comparative perspective. Retrieved May 10, 2013 fromhttps://www.google.com.np/url?sa=f\&rct=j\&url=http:// ijoc.org/ojs/index.php/ijoc/article/download/754/431\&q=\&e $\mathrm{src}=\mathrm{s} \& \mathrm{ei}=\mathrm{cLCbUbn} 1 \mathrm{FYjyrQfZvIDQDg} \& u s g=\mathrm{AFQjCNHL}$ dZQ0v2Tf8zcR-gx0aGmVU_jd0g

Voltmer, Katrin. (2008). Comparing media systems in new democracies: East meets South meets West. Retrieved January 8, 2019 from https://www.researchgate.net/publication/238733427_Comp aring_media_systems_in_new_democracies East_meets_South_meets_West

The author is the chairperson of the Center for Media Research Nepal. 